\title{
Pendugaan Kadar Air Beras Ketan Putih Dengan Teknologi NIRS Menggunakan Metode Principal Component Regression (Pretreatment De-trending, Derivative-2, dan Standart Normal Variate)
}

\author{
Mardiantono $^{1}$, Fachruddin $^{1}$, Zulfahrizal $^{1}{ }^{*}$ \\ ${ }^{1}$ Program Studi Teknik Pertanian, Fakultas Pertanian, Universitas Syiah Kuala \\ *Coresponding author: zulfahrizal@unsyiah.ac.id
}

\begin{abstract}
Abstrak. Kadar Air merupakan salah satu komponen penting dalam beras ketan putih yang dapat mempengaruhi kualitas dari beras ketan putih. Penelitian ini bertujuan menguji dan mengevaluasi teknologi NIRS sebagai metode cepat dan tepat dalam memprediksi kadar air beras ketan dengan metode Principal Component Regression (PCR) serta menentukan metode koreksi spektrum yang terbaik dan akurat untuk memprediksi kadar air beras ketan dengan menggunakan pretreatment De-Trending, Derivative-2, dan Standart Normal Variate (SNV). Penelitian ini menggunakan beras ketan putih yang didapat dari pasar Rukoh Banda Aceh, yang berjumlah 35 sampel. Perlakuan yang diberikan adalah tanpa perendaman, dibasahi, dan perendaman selama 5, 10, 15, 20, dan 25 menit. Prediksi kadar air beras ketan dengan NIRS menggunakan alat self developed FT-IR IPTEK T-1516 dan metode referensi yang digunakan adalah metode gravimetri yang berdasarkan pada Association of Official Analytical Chemists (AOAC). Pengolahan data menggunakan Unsclambers sofware ${ }^{\circledR} X$ version 10.5 . Hasil penelitian menunjukkan bahwa NIRS dengan metode PCR mampu menghasilkan model yang baik untuk pendugaan beras ketan. Penelitian ini menghasilkan empat model pendugaan kadar air beras ketan dimana satu model tergolong very good performance (RPD $>3$ ) dan tiga model tergolong good model performance (RPD $>2$ ) sehingga dapat dikatakan bahwa semua model yang dihasilkan layak dan baik untuk pendugaan kadar air beras ketan. Pretreatment terbaik pada penelitian ini adalah Standart Normal Variate (SNV) dengan nilai RPD 3,12, r sebesar 0,95, $\mathrm{R}^{2}$ sebesar 0,89, dan RMSEC sebesar 2,34.
\end{abstract}

Kata Kunci : NIRS, De-Trending, Derivative-2, SNV, Kadar Air, Beras Ketan Putih

\begin{abstract}
Water content is one important component in white glutinous rice which can affect the quality of white glutinous rice. This study aims to test and evaluate NIRS technology as a fast and precise method for predicting glutinous rice water content with the Principal Component Regression (PCR) method and determine the best and accurate spectrum correction method for predicting glutinous rice water content using the De-Trending, Derivative pretreatment -2 , and Standard Normal Variate (SNV). This study uses white sticky rice obtained from the Rukoh market in Banda Aceh, which amounted to 35 samples. The treatment given is without soaking, soaking, and soaking for 5, 10, 15, 20, and 25 minutes. The prediction of glutinous rice moisture content with NIRS uses a self-developed FT-IR IPTEK T-1516 tool and the reference method used is the gravimetric method based on the Association of Official Analytical Chemists (AOAC). Data processing using Unsclambers software X version 10.5. The results showed that NIRS with the PCR method was able to produce a good model for estimating glutinous rice. This study produced four models of estimation of glutinous rice water content where one model was classified as very good performance (RPD> 3 ) and three models were classified as good model performance (RPD>2) so that it could be said that all the models produced were suitable and good for estimating rice water content sticky rice. The best pretreatment in this study is the Standard Normal Variate (SNV) with an RPD value of 3.12, $\mathrm{r}$ of $0.95, \mathrm{R}^{2}$ of 0.89 , and RMSEC of 2.34 .
\end{abstract}

Keywords : NIRS, De-Trending, Derivative-2, SNV, Water content, White Glutinous Rice 


\section{PENDAHULUAN}

Indonesia adalah salah satu negara agraris yang memiliki banyak bahan pangan, salah satunya adalah beras ketan putih (Oryza Sativa L. Var Glutinosa) yang terdapat cukup banyak di Indonesia. Beras ketan memiliki kandungan karbohidrat yang cukup tinggi yang dapat dijadikan sebagai makanan pokok untuk di konsumsi sehari-hari. Karakteristik yang sangat penting pada bahan pangan termasuk beras ketan adalah kadar air, karena air dapat mempengaruhi mutu serta daya simpan bahan pangan tersebut. Beras ketan dengan kadar air tinggi akan menyebabkan beras ketan menjadi rusak, busuk, berjamur dan berubah warna, sedangkan beras dengan kandungan air rendah akan menyebabkan beras ketan mudah pecah atau retak.

Pengukuran kadar air biasanya dilakukan yang membutuhkan waktu cukup lama dan merusak karakter fisik beras ketan (destruktif). Selain itu juga dapat menggunakan alat elektronik seperti moisture tester yang bersifat non destruktif dan mudah dibawabawa. Seiring dengan berkembangnya teknologi, metode spektroskopi NIRS telah menjadi perhatian beberapa dekade terakhir.

Penelitian NIRS yang terkait beras diantaranya chen et al. (2018), mendeteksi keaslian beras hitam dengan melihat protein, air, amilosa dan asam lemak dari beras hitam dengan menggunakan metode PCA. Nurhasanah et al. (2019) memprediksi kadar air beras dengan teknologi NIRS menggunakan metode PLS. Masyitah et al. (2019) menguji keaslian Beras Aceh dengan teknologi NIRS menggunakan metode PCA. Firdaus et al. (2017) mendeteksi kadar air, protein, dan asam lemak dari benih padi dengan membangun model menggunakan metode JST. Sari et al. (2019) memprediksi kadar air gabah dengan teknologi NIRS menggunkan metode PCR.

Oleh karena itu, tujuan dari penelitian ini adalah menguji dan mengevaluasi teknologi NIRS sebagai metode cepat dan tepat dalam memprediksi kadar air beras ketan putih dengan metode Principal Component Regression (PCR) dan menentukan metode koreksi spektrum yang terbaik dan akurat untuk memprediksi kadar air beras ketan putih dengan menggunakan pretreatment De-Trending, Derivative-2, dan Standart Normal Variate (SNV).

\section{METODOLOGI PENELITIAN}

\section{Alat dan Bahan}

Alat yang digunakan pada panelitian ini adalah Self developed FT-IR IPTEK T1516, oven, cawan petri porselin, botol plastik, timbangan digital, tisu, mangkuk, desikator dan unsclamber sofware ${ }^{\circledR} X$ Version 10.5 . Bahan yang digunakan pada penelitian ini adalah beras ketan putih (Oryza Sativa L. Var Glutinosa) didapat dari pasar Rukoh, Darussalam, Banda Aceh.

\section{Persiapan Beras Ketan}

Perlakuan yang diberikan pada beras ketan yaitu perendaman, dibasahi dan tanpa perendaman. Perendaman beras dilakukan menggunakan air hangat dengan suhu sekitar $45^{\circ} \mathrm{C}$ selama 5, 10, 15, 20 dan 25 menit. Perendaman dilakukan dengan air hangat untuk mendapatkan variasi nilai kadar air dari beras ketan yang nantinya digunakan untuk menguji atau melihat dari kehandalan model prediksi kadar air yang didapatkan. Kemudian beras ketan dibagi menjadi dua bagian yaitu untuk pengujian kadar air dengan 
metode gravimetri dan akuisisi spektrum NIR. Masing- masing metode terdiri dari 35 sampel, dimana untuk pengujian metode gravimetri berat sampel yaitu 5 gram dan akuisisi spektrum yaitu 20 gram.

\section{Uji Kadar Air Laboratorium}

Pengujian kadar air menggunakan metode gravimetri yang berdasarkan pada Association of Official Analytical Chemists (AOAC) (2005). Perhitungan kadar air menggunakan rumus:

$$
\text { KA }(\% \text { Basis Basah })=\frac{M 1-M 2}{M 1-M 0} \times 100 \%
$$

Keterangan:

$\mathrm{KA}=$ Kadar air $(\%$ Basis Basah $)$

$\mathrm{M}_{1}=$ Bobot cawan dengan sampel sebelum di oven (gram) $\mathrm{M}_{2}=$ Bobot cawan dengan sampel setelah di oven (gram) $\mathrm{M}_{0}=$ Bobot cawan kosong (gram)

\section{Pengaturan Alat NIRS}

Adapun instrument utama yang akan digunakan untuk memprediksi kadar air pada penelitian ini adalah self developed FT-IR IPTEK T-1516. Menurut Zulfahrizal et al., (2017) menyatakan instrument ini meradiasikan gelombang cahaya pada kisaran Panjang gelombang antara 1000 sampai $2500 \mathrm{~nm}$ dan dikontrol oleh perangkat lunak Thermo Integration ${ }^{\circledR}$. Spektrum NIRS didapatkan menggunakan self developed FT-IR IPTEK T 1516 dengan konfigurasi alur kerja alat (workflow) dibangun dengan menggunakan perangkat lunak terintegrasi Thermo Integration ${ }^{\circledR}$. Workflow dibuat untuk mengatur alat agar berkerja untuk mengakuisisi spektrum diffuse reflectance sampel, lalu merataratakan hasilnya dan menyimpan hasil pemindaiannya dalam tiga bentuk file yaitu *.SPA *.JDX dan

*.CSV.

\section{Akuisisi Spektrum NIRS}

Akuisisi Spektrum beras ketan dilakukan dalam bentuk tumpukan. MasingMasing sampel yang telah dimasukkan ke dalam botol plastik akan dilakukan pengambilan spektrum dengan cara diletakkan masing-masing sampel tersebut pada lubang sinar. Data absorban diperoleh dengan cara mentransformasikan nilai reflektan ke dalam bentuk Log $(1 / \mathrm{R})$.

\section{Pemeriksaan Data Outlier dan Koreksi Spektrum}

Data outlier di remove dengan menggunakan metode Principal Component Analysis (PCA) dan hotelling $\mathrm{T}^{2}$ elllipse yang merupakan cara untuk menganalisa data pencilan. Data yang diambil adalah data yang berada didalam garis elips, jika berada diluar garis elips, maka data tersebut ditandai sebagai data pencilan (outlier) dan dihilangkan (remove) (Cozolino et al., 2011)

Sebelum digunakan untuk Analisa data (membangun model prediksi), spektrum NIR untuk semua sampel terlebih dahulu dilakukan koreksi spektrum. Hal ini bertujuan untuk menghilangkan berbagai macam noise pada spektrum sampel agar hasil prediksi 
lebih akurat (Mouazen et al., 2010). Adapun pretreatment yang digunakan pada penelitian ini adalah Standard Normal Variate, De-Trending dan Derevative 2. Model prediksi dibangun dengan metode Principal Component Regression (PCR) untuk memprediksi kadar air beras ketan putih.

\section{Pembuatan Model Kalibrasi}

Kadar air beras ketan diprediksi dengan cara membangun model berdasarkan data dari akuisisi spektrum NIRS (variabel X) dan data kadar air yang menggunakan metode gravimetri dari hasil pengukuran di laboratorium (variabel Y). Model prediksi dibangun dengan menggunakan metode Principal Component Regression (PCR). Keseluruhan datadipakai sebagai dataset kalibrasi yang digunakan untuk membangun model prediksi kadar air.

Evaluasi keakuratan model dievaluasi dengan melihat parameter statistik yang meliputi; koefisien korelasi (r), koefisien determinasi $\left(\mathrm{R}^{2}\right)$, root mean square error (RMSE), Residual Predictive Deviation Index (RPD), dan jumlah latent variable (LV). . Model yang bagus memiliki nilai $r$ dan $\mathrm{R}^{2}$ yang tinggi, RMSEC yang rendah, $\mathrm{RPD}>1,5$ dan latent variable $<9$; RMSEC, RPD dicari dengan persamaan (Florez et al., 2009 ; Jha, et al., 2006 ; Nicolai et al., 2007 ; Zulfahrizal et al., 2015).

\section{HASIL DAN PEMBAHASAN}

\section{Sampel Penelitian}

Pada penelitian ini sampel yang digunakan adalah beras ketan putih (Oryza Sativa L. Var Glutinosa) dengan berbagai perlakukan yang dilakukan yakni berupa variasi lama perendaman. Sampel yang digunakan adalah 35 sampel yaitu masing-masing 5 sampel dari beras ketan tanpa perendaman, dibasahi, direndam 5, 10, 15, 20, dan 25 menit. Beras ketan dibagi menjadi dua bagian yaitu untuk pengujian kadar air di laboratorium dan memprediksi kadar air menggunakan NIRS. Pada pengujian kadar air laboratorium metode yang digunakan adalah metode gravimetri sedangkan metode untuk uji kadar air dengan teknologi NIRS menggunakan metode PCR (Principal Component Regression).

\section{Spektrum Awal Beras Ketan}

Spektrum Awal merupakan hasil pengambilan spektrum NIRS pada selang panjang gelombang 1000-2500 $\mathrm{nm}$ tanpa menggunakan metode koreksi (pretreatment). Spektrum awal pada penelitian ini telah memberikan informasi akan adanya kandungan air dalam beras ketan, yang dapat dilihat pada Gambar 1 .

Spektrum awal beras ketan menampilkan dua puncak kandungan air yaitu 1902$1962 \mathrm{~nm}\left(5257-5095 \mathrm{~cm}^{-1}\right)$ untuk puncak pertama dan 1407-1478 nm (7104-6765 cm $\left.{ }^{-1}\right)$ untuk puncak kedua. Panjang gelombang yang didapat pada Penelitian ini sesuai dengan penelitian sebelumnya yang meneliti kadar air dengan NIRS. Pada penelitian Nurhasanah et al. (2019) kandungan air pada beras berada di panjang gelombang 1881-1970 nm $\left(5314-5075 \mathrm{~cm}^{-1}\right)$ dan 1406-1455 nm (7108-6869 $\left.\mathrm{cm}^{-1}\right)$. Pada penelitian Chen et al. (2018) penyerapan air pada beras hitam berada di panjang gelombang $1932 \mathrm{~nm}$ (5175 $\left.\mathrm{cm}^{-1}\right)$ dan $1443\left(6930 \mathrm{~cm}^{-1}\right)$. Pada penelitian Sari et al. (2019) kandungan air pada gabah berada pada panjang gelombang $1869-2014 \mathrm{~nm}\left(5350-4964 \mathrm{~cm}^{-1}\right)$ dan $1374-1451 \mathrm{~nm}$ (7278-6892 $\left.\mathrm{cm}^{-1}\right)$. Pada penelitian Firdaus et al. (2014) kandungan air benih padi 
terdapat pada $1940 \mathrm{~nm}\left(5154 \mathrm{~cm}^{-1}\right)$ dan $1450 \mathrm{~nm}\left(6896 \mathrm{~cm}^{-1}\right)$.

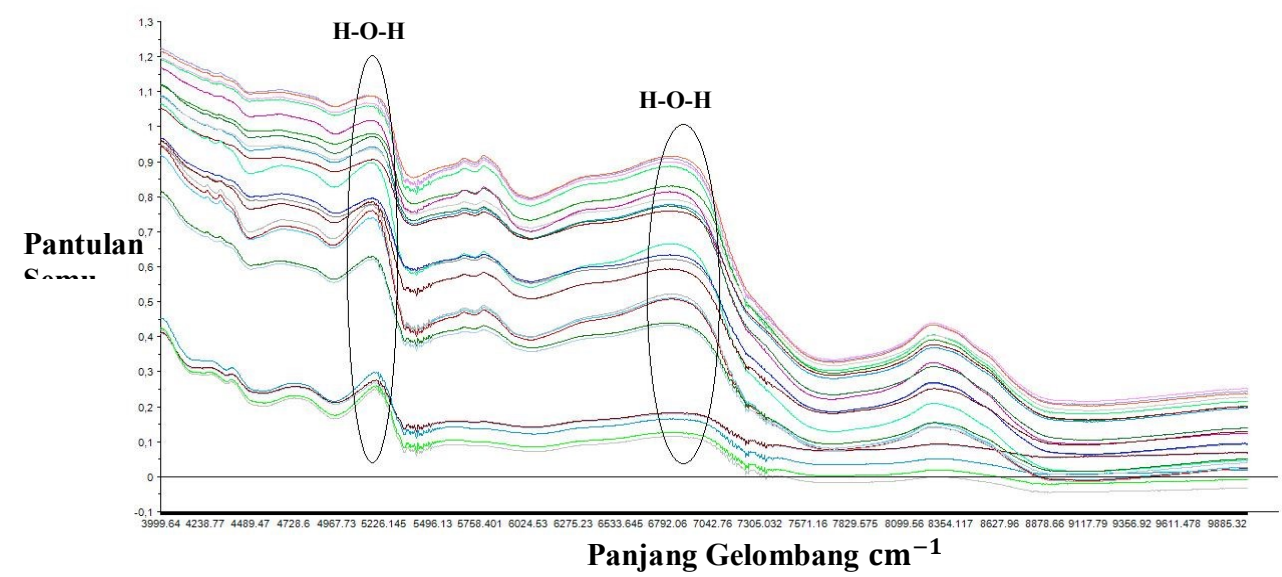

Gambar 1. Spektrum awal kadar air beras ketan

Panjang gelombang optimum pengujian kadar air dapat dilihat pada loading plot. Menurut Zulfahrizal (2014), bahwa puncak tertinggi pada loading plot menandakan panjang gelombang optimum yang menunjukkan adanya kandungan kadar air. Berdasarkan Gambar 2 terdapat dua puncak yang menandakan kandungan kadar air beras ketan yang berada pada rentang 1905-1953 nm (5249-5129 $\left.\mathrm{cm}^{-1}\right)$ dan 1423-1471 nm $\left(7027-6798 \mathrm{~cm}^{-1}\right)$.

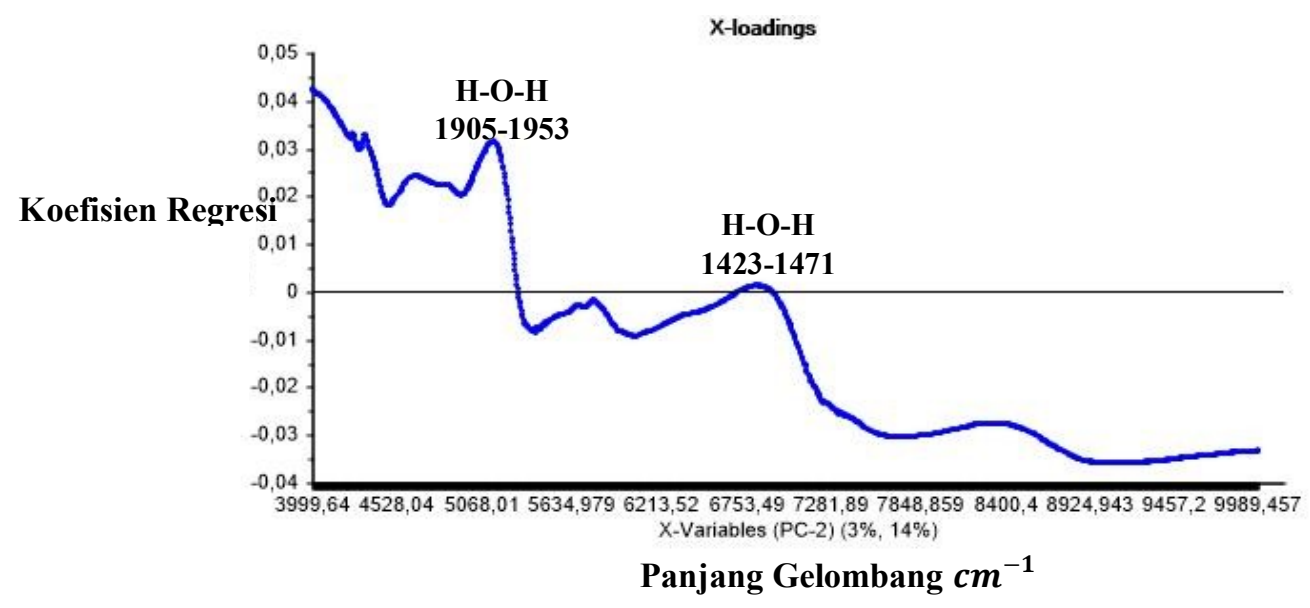

Gambar 2. Loading Plot Non-Pretreatment dengan Metode PCR

\section{Analisa Data Outlier}

Data Outlier atau data pencilan merupakan suatu data yang berbeda dengan datadata lainnya yang dapat mengganggu data pendugaan pada saat kalibrasi spektrum. Data outlier dideteksi menggunakan metode Principal Component Analysis (PCA) dan Hotteling 2 ellipse. Pemeriksaan data outlier dapat dilihat pada Gambar 3. 


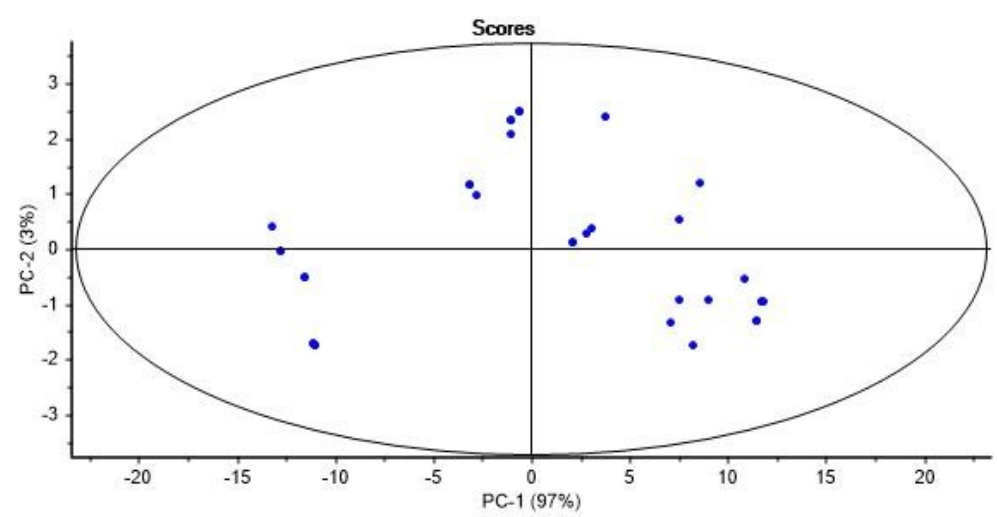

Gambar 3. Pemeriksaan Data Outlier dengan Metode PCA dan Hotteling ${ }^{2}$ Ellipse

Setelah analisa data pencilan dilakukan, hasil yang didapat tidak ada data pencilan dan data pengungkit dalam data kadar air beras ketan sehingga dapat dilanjutkan ke tahap selanjutnya yakni analisa spektrum kadar air beras ketan tanpa ada data yang harus dibuang.

\section{Koreksi Spektrum NIRS}

Analisa spektrum NIRS dilakukan pada raw spektrum dan spektrum yang menggunakan metode koreksi atau pretreatment. Pada penelitian ini pretreatment yang digunakan adalah De-Trending, Derivative-2, dan Standart Normal Variate (SNV), yang nantinya akan dipilih metode koreksi (pretreatment) terbaik untuk memprediksi kadar air beras ketan.

\section{Pretreatment De-Trending}

Pretreatment De-trending mampu menghapus trend nonlinear pada data spektrum. Gambar 4 merupakan spektrum kadar air beras ketan menggunakan pretreatment de-trending puncak pertama berada pada panjang gelombang rentang 1898 $1982 \mathrm{~nm}\left(5268-5044 \mathrm{~cm}^{-1}\right)$ dan 1403-1 588 nm $\left(7127-6294 \mathrm{~cm}^{-1}\right)$.

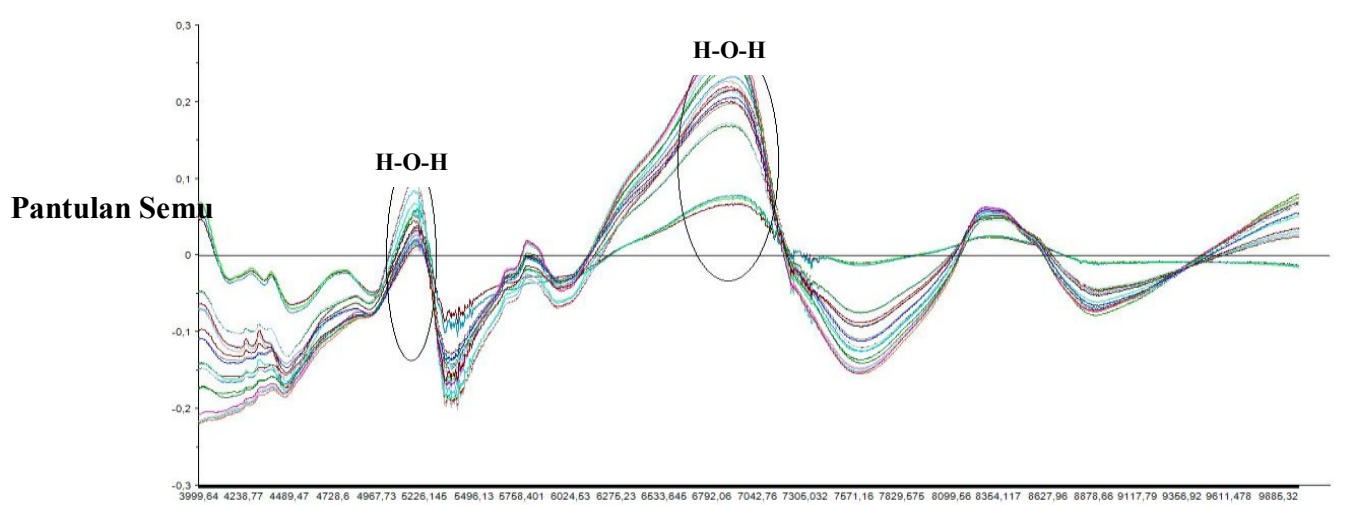

Panjang Gelombang $\mathbf{c m}^{-1}$

Gambar 4. Spektrum Beras Ketan dengan Pretreatment De-Trending 


\section{Pretreatment Derivative-2}

Penggunaan pretreatment Derivative-2 telah berhasil menghilangkan baseline dan mempertajam perbedaan spektrum sehingga serapan spektrum tidak saling tumpang tindih maka pola spektrumnya terlihat jelas. Spektrum yang telah diberikan pretreatment Derivative-2 dapat dilihat pada Gambar 5 yang mana puncak pertama yang menandakan adanya kandungan air berada pada panjang gelombang kisaran 1841-1893 nm (5430-5280 $\left.\mathrm{cm}^{-1}\right)$ dan puncak kedua 1348-1414 $\mathrm{nm}\left(7413-7069 \mathrm{~cm}^{-1}\right)$.

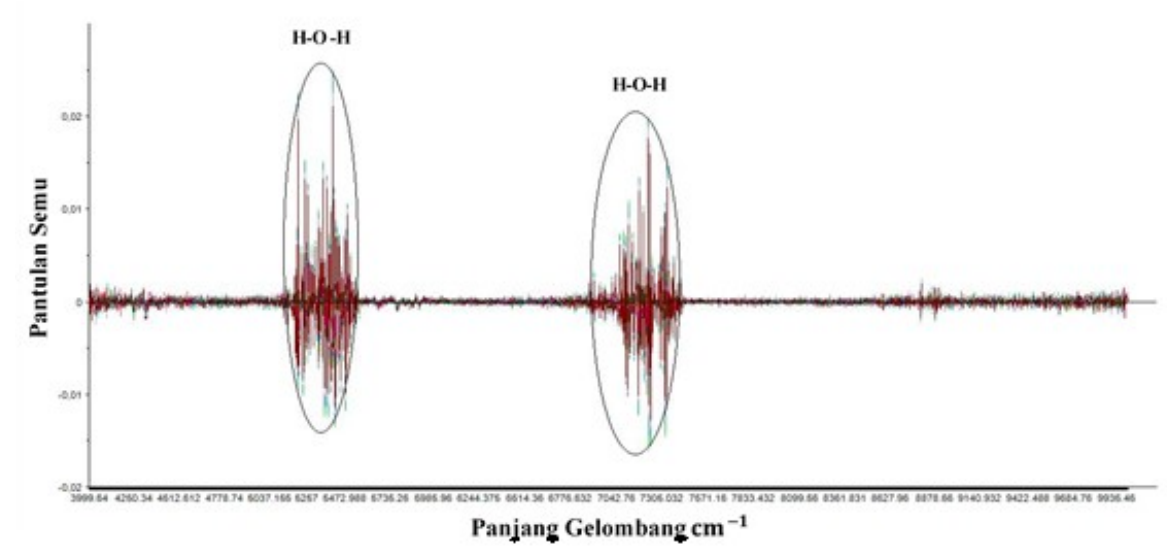

Gambar 5. Spektrum Beras Ketan dengan Pretreatment Derivative-2

\section{Pretreatment Standart Normal Variate (SNV)}

Pretreatment Standart Normal Variate (SNV) berhasil menghilangkan scatter effects (penyebaran efek) dari spektrum, sehingga spektrum beras ketan yang dihasilkan lebih bagus. Pada Gambar 6 terlihat bahwa terdapat dua puncak yang memiliki kandungan air yaitu puncak pertama terdapat pada panjang gelombang kisaran 1903-1970 nm (5253-5075 $\mathrm{cm}^{-1}$ ) dan pada puncak kedua kandungan air terdapat pada panjang gelombang 1423-1483 $\mathrm{nm}\left(7023-6741 \mathrm{~cm}^{-1}\right)$.

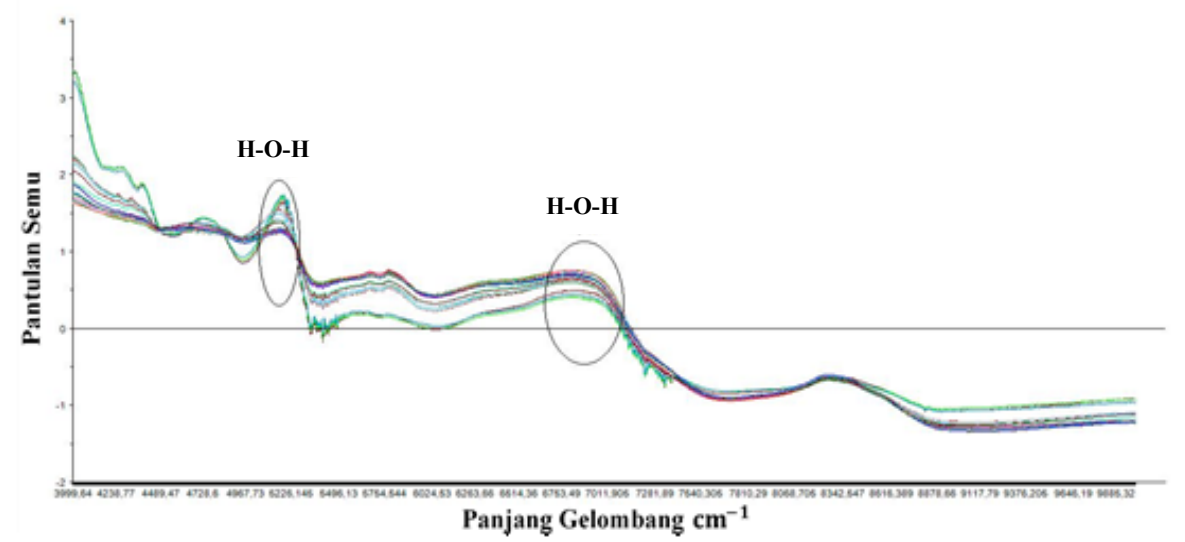

Gambar 6. Spektrum Beras Ketan dengan Pretreatment SNV 


\section{Pengembangan Model Kalibrasi Principal Component Regression (PCR)}

Model kalibrasi digunakan untuk membangun model persamaan matematik yang dapat digunakan untuk memprediksi kandungan kimia bahan pangan tanpa harus melakukan pengukuran langsung secara destruktif yang dapat merusak bahan. Proses kalibrasi menggunakan 35 sampel beras ketan. Selanjutnya dibuat acuan pengukuran untuk sampel kalibrasi seperti selang antar sampel, rataan, dan standar deviasi (SD) sampel dari pengukuran secara thermogravimetri di laboratorium dapat dilihat pada Tabel 1 .

Tabel 1. Acuan Pengukuran Data Kalibrasi

\begin{tabular}{|c|c|c|c|c|}
\hline \multirow[t]{3}{*}{ Bagian } & \multirow[t]{3}{*}{ Jumlah Data } & \multicolumn{3}{|c|}{ Kadar } \\
\hline & & Air & & \\
\hline & & Maksimum & Minumum & Standar Deviasi \\
\hline Kalibrasi & 35 & 33,56 & 11,51 & 7,29 \\
\hline
\end{tabular}

Tabel 1 merupakan acuan pengukuran data kalibrasi, dapat dilihat bahwa data memiliki keberagaman yang cukup besar dengan nilai standar deviasi 7,29 dengan nilai maksimum sebesar 33,56 dan nilai minimum sebesar 11,51 yang diperoleh dari hasil analisis laboratorium. Interpretasi pengembangan model kalibrasi PCR pada pendugaan kadar air beras ketan menggunakan NIRS dengan nonpretreatment dan pretreatment dapat dilihat pada Tabel 2.

Tabel 2. Hasil Interpretasi Pengembangan Model Kalibrasi PCR

\begin{tabular}{lccccc}
\hline Perlakuan & Latent Variable & $\mathrm{R}^{2}$ & $\mathrm{r}$ & $\mathrm{RMSEC}(\%)$ & $\mathrm{RPD}$ \\
\hline Non pretreatment & 4 & 0,81 & 0,89 & 3,17 & 2,29 \\
De-Trending & 4 & 0,83 & 0,91 & 2,93 & 2,49 \\
Derivative 2 & 4 & 0,82 & 0,91 & 3,05 & 2,39 \\
Standart Normal Variate & 4 & 0,89 & 0,95 & 2,34 & 3,12 \\
\hline
\end{tabular}

Hasil interpretasi pengembangan model kalibrasi PCR tersebut dapat dikatakan bahwa semua model prediksi kadar air beras ketan dengan metode PCR dapat memprediksi kadar air beras ketan dengan baik. Selain itu jug dapat disimpulkan bahwa pretreatment terbaik yang digunakan untuk prediksi kadar air beras ketan menggunakan NIRS dengan metode PCR adalah pretreatment Satndart Normal Variate (SNV), karena nilai RPD yang didapat yaitu sebesar 3,12 yang merupakan nilai RPD termasuk golongan sangat baik, nilai koefisien determinasi $\left(R^{2}\right)$ yang dihasilkan pretreatment SNV yaitu sebesar 0,89 , kemudian nilai root mean square error calibration (RMSEC) yang didapat sebesar 2,34 dan latent variable yang digunakan adalah 4. 


\section{KESIMPULAN DAN SARAN}

\section{Kesimpulan}

Adapun berdasarkan penelitian yang telah dilakukan oleh peneliti maka dapat diperoleh kesimpulan sebagai berikut :

1. Teknologi NIRS mampu menduga kadar air beras ketan putih yang dapat dideteksi pada panjang gelombang 1912-1962 nm dan 1407-1478 nm serta panjang gelombang optimum berada pada panjang gelombang 1905-1968 nm.

2. Aplikasi teknologi NIRS dengan metode PCR menghasilkan empat model pendugaan kadar air beras ketan, satu model tergolong very good performance (RPD $>3$ ) dan ketiga model lainnya tergolong good model performance (RPD $>2$ ) sehingga dapat dikatakan bahwa semua model yang dihasilkan layak dan baik untuk pendugaan kadar air beras ketan.

3. Model pendugaan kadar air terbaik adalah model yang menggunakan pretreatment Standart Normal Variate (SNV) dengan predikat very good model performance dimana menghasilkan nilai latent variable 4, nilai RPD sebesar 3,12, r sebesar 0,95, R² sebesar 0,89, dan RMSEC sebesar 2,34.

\section{Saran}

Adapun saran dari penelitian ini adalah sebaiknya pada penelitian lanjutan mengukur komponen kimia selain kadar air sehingga dapat memberikan informasi nilai komponen kimia lain dari beras ketan.

\section{DAFTAR PUSTAKA}

AOAC. 2005. Official Methods of Analysis Assosiation of Official Analytical Chemists Benjamin Franklin Station, Washington DC.

Chen, H., C. Tan, Z. Lin 2018. Authenticaty Detection of Black Rice by Near Infrared Spectroscopy and Support Vector Data Description. International Journal of Analytical Chemistry. 2018: 1-8.

Cozzolino, D., W. U. Cynkar, N. Shah, P. Smith. 2011. Multivariate Data Analysis Using Appliedto Spectroscopy: Potential Application to Juice and Fruit Quality. Food Research International, 44: 1888-1896.

Firdaus, J., dan U. Ahmad. 2017. Deteksi Benih Varietas Padi Menggunakan Gelombang Near Infrared dan Model Jaringan Saraf Tiruan, 1 (1), 29-36.

Florez, K., M.T. Sanchez, D. Perez-Marin, J.E. Guererro, A.G. Varo. 2009. Feasibility in NIRS Instrument for Predicting Internal Quality in Intact Tomato. Jurnal Food Engineering. 91:311-318. InfraredSpectrosc. 13: 87-97.

Jha, S.N., A.R.P. Kinsly, S. Chopra. 2006. Non-Destruktif Determination of Firmness and Yellowness of Mango During Growth and Storage Using Visual Spectroscopy. Jurnal Biosystem Engineering. 93:397-402.

Masyitah., Syahrul., Zulfahrizal. 2019. Pengembangan Metode Pengujian Keaslian Beras Aceh Menggunakan NIRS Dengan Metode PCA. Jurnal Ilmiah Mahasiswa Pertanian Unsyiah. 4: 5-8.

Mouazen, A. M., W. Saeys, J. Xing, J. D. Baerdemaeker, H. Ramon. 2010. Near Infrared 
Nicolai, B.M., K. Beullens, E. Bobelyn, A. Peirs, W. Saeys, K.I. Theron, J. Lamertyn. 2007. Non-Destructive Measturement of Fruit and Vegetable Quality by Means of NIR Spectroscopy : A Review. Postharvest Biology and Technology. 46:99118.

Nurhasanah., K. Siregar., Zulfahrizal. 2019. Prediksi Kadar Air Beras Menggunakan NIRS Dengan Metode PLS dan Pretreatment Standard Normal Variate, Derivative-1, Savitzky Golay Smoothing. Jurnal Ilmiah Mahasiswa Pertanian Unsyiah. 3: 4-8

Sari M., I. S. Nasution., dan Zulfahrizal. 2019. Prediksi Kadar Air Gabah Menggunakan Near Infrared Reflectance Spectroscopy dengan Metode Principal Component Regression (pretreatment MSC, Derivative 1 dan De-Trending). Jurnal Ilmiah Mahasiswa Pertanian Unsyiah. 3: 4-7

Spectroscopy for Agricultural Materials: An Instrument Comparison. J Near

Zulfahrizal. 2014. Pengembangan Metode Pengukuran Non-Destruktif untuk Menentukan Mutu dan Fermentasi Biji Kakao Utuh Menggunakan NIR Spectroscopy. Disertasi. Institut Pertanian Bogor, Bogor.

Zulfahrizal., A. A. Munawar, dan H. Meilina. 2015. Rancang Bangun Alat Sensor Portable Berbasis Pengembangan Aplikasi Teknologi Near Infrared Sebagai Metode Baru yang Rapid dan Non-Destructive untuk Prediksi Kualitas Kakao. Laporan Penelitian. Universitas Syiah Kuala, Banda Aceh.

Zulfahrizal., A. A. Munawar, dan H. Meilina. 2017. Rancang Bangun Alat Sensor Portable Berbasis Pengembangan Aplikasi Teknologi Near Infrared Sebagai Metode Baru yang Rapid dan Non-Destructive untuk Prediksi Kualitas Kakao. Prosiding Seminar Nasional Pasca Sarjana (SNP) Universitas Syiah Kuala di Banda Aceh 13 April 2017. 32-37. 